\title{
Saline Intrusion Response to Sea Level Rise and Its Implications on Water and Coastal Management: A Case Study in Brazil
}

\author{
Raquel Toste', Paulo C. C. Rosman ${ }^{2}$, Marcos A. V. de Freitas ${ }^{3}$ \\ ${ }^{1}$ Laboratory for Computational Methods in Engineering, Federal University of Rio de Janeiro, Rio de Janeiro, Brazil \\ ${ }^{2}$ Department of Oceanic Engineering, Federal University of Rio de Janeiro, Rio de Janeiro, Brazil \\ ${ }^{3}$ Department of Energetic Planning, Federal University of Rio de Janeiro, Rio de Janeiro, Brazil \\ Email: rtoste@gmail.com
}

How to cite this paper: Toste, R., Rosman, P.C.C. and de Freitas, M.A.V. (2017) Saline Intrusion Response to Sea Level Rise and Its Implications on Water and Coastal Management: A Case Study in Brazil. Journal of Water Resource and Protection, 9, 510522.

https://doi.org/10.4236/jwarp.2017.95033

Received: March 18, 2017

Accepted: April 27, 2017

Published: April 30, 2017

Copyright (c) 2017 by authors and Scientific Research Publishing Inc. This work is licensed under the Creative Commons Attribution International License (CC BY 4.0).

http://creativecommons.org/licenses/by/4.0/

\section{(c) (i) Open Access}

\begin{abstract}
Global temperature is predicted to increase in the end of the century and one of the primary consequences of this warming is the sea level rise. Considering the vulnerabilities on coastal systems and water resources, it is important to evaluate the potential effects of this rising in coastal areas, since the saline intrusion on rivers would be intensified, leading to problems related to water quality. In this context, the present work aimed to verify saline intrusion changes along an important river, São Francisco Canal, located in Rio de Janeiro State, Brazil. For this purpose, a hydrodynamic modeling was performed using SisBaHiA, considering different sea levels and tide conditions. According to the results, it was verified the intensification on saline intrusion and higher salinity values due to a sea level rise of $0.5 \mathrm{~m}$. These results show that new licenses for water withdrawals must be carefully analyzed as the fluvial flow plays an important role to contain the saltwater intrusion on the studied river. Accordingly, it is recommended the evaluation of climate change effects in order to choose best strategies to reduce coastal vulnerability, and the use of this theme on environmental licensing and territorial planning, integrating water planning with coastal management.
\end{abstract}

\section{Keywords}

Saline Intrusion, Sea Level Rise, Water Resource Management

\section{Introduction}

Climate change and its effects on the environment and human life have been increasingly discussed and considered in the present society. Despite the increas- 
ing on greenhouse gas (GHG) emissions after Industrial Revolution, the causes of the global warming are not straightforward. Nevertheless, even natural or human-caused, the climate change effects should be considered and investigated in different scales and spheres both for global and regional planning.

This increasing on global surface temperature has already been observed in the present days. According to IPCC (Intergovernmental Panel on Climate Change), the global temperature increased $0.74^{\circ} \mathrm{C}$ along the 20th century and its effects could also be observed on the global hydrological cycle [1]. It includes the global mean sea level (SL) rise observed in a rate of $1.7 \mathrm{~mm}$ per year [2]. However, for the next century, the SL is predicted to rise on speeder rates [1].

These projections are an important issue, mainly considering the coastal vulnerability to sea level rise in addition to the effects of potential changes on winds, waves and on the frequency of climate extremes. Among others, the SL rise leads to problems associated to coastal flooding and contamination of coastal aquifers. However, these effects vary according to regional characteristics being important to study different environments and regions [3].

In Brazil, just few studies have been realized considering climate change effects on coastal zones. Despite of this, in some regions, comprising the coastal zone of the state of Rio de Janeiro, losses associated to extreme events are being experienced. These current evidences of SL rising effects on coastal environments demonstrate that further investigation is a necessary and strategic factor [4]. However, due to the absence of historical information about the SL on the Brazilian coast, the coastal vulnerability in the country is also due to these uncertainties about past SL changes and their scales [5].

According to global climate models, the average prediction for global SL rise along the 21 st century is about $0.47 \mathrm{~m}$ in relation to the mean SL for 1986-2005. For 2100 , this change is projected in $0.53 \mathrm{~m}$ to the same reference period [6]. These projections were realized considering the stabilization scenario RCP4.5 reported on the Fifth Assessment Report by IPCC (Intergovernmental Panel on Climate Changes). In a regional scale, Belém [7] estimated SL oscillations along the Brazilian coast considering local salinity and temperature data and predicted an average rise of $0.50 \mathrm{~m}$ for the next 50 - 100 years.

This projected rise would deteriorate water quality, since saline wedge reaches inshore regions of the coastal aquifers. Saline intrusion is a serious environmental condition as $80 \%$ of the world's population live on coastal zones and use local aquifers for their water supply [8]. Thus, these long-term changes should be evaluated, since just few centimeters of SL rise can cause significant damages. Additionally, the combined effect of withdrawals and the SL rise on saline intrusion requires management actions to protect water resources, as the water conditions appropriated for human use may be affected [9]. Hence, many studies are necessary to understand those effects on ecosystems and human well-being.

In some regions, saline intrusion on coastal aquifers may be intensified by lower rainfall rates, what decreases the water availability for human supply, as previously observed in Senegal [10]. In Brazil, some studies were realized but 
there is still a lack of investigations linking saline intrusion to climate change. Thus, the present research is important to understand and predict further potential stresses on water resources. In this sense, the present work aimed to estimate the influence of SL rise on the saline intrusion in São Francisco Canal (Brazil), using numerical modeling, in order to verify possible implications on water management.

\section{Material and Methods}

São Francisco Canal is one of the main aquifers located in Rio de Janeiro State, Brazil (Figure 1), and it plays an important role on the regional economical development supplying great industries. This river corresponds to the downstream section of Guandu River and it flows to Sepetiba bay, being influenced by tide action. Its fluvial flow is controlled by the water transferred from Paraíba do Sul River to Guandu river basin, what results in an average flow of $108 \mathrm{~m}^{3} / \mathrm{s}$ [11]. However, the actual flow depends on the waters released by an hydroelectric power plant (HPP), called Pereira Passos HPP, which controls the total volume flowing to the bay, being important to control the saline wedge penetration.

To verify the saline intrusion on the studied region, hydrodynamic and dispersion modeling were performed using SisBaHia (Sistema Base de Hidrodinâmica Ambiental) system. This system corresponds to a finite element hydrodynamic numerical model governed by barotropic forcing and optimized for natural water bodies where the effects of variable density can be neglected. This model is based on principle of conservation of momentum what, in conjunction with the continuity equation, the equation of state and the respective constituent transport equations, constitute the fundamental mathematical model for any water body [12].

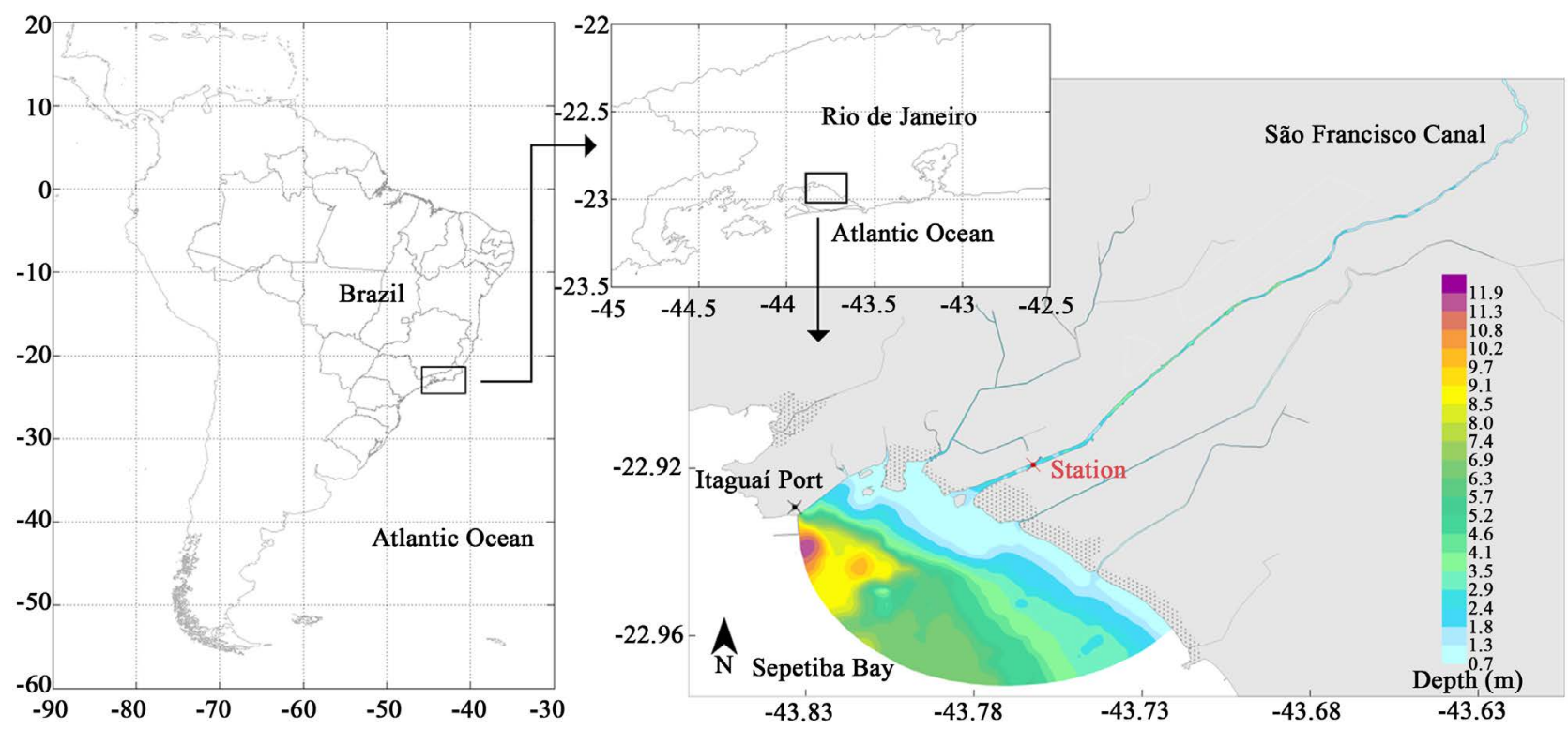

Figure 1. Representation of the study area and the bathymetry of the grid domain, in meters, used on the hydrodynamic model. The position of the grid point where modeled salinity and water level time series were extracted is marked in red (station). 
Eulerian transport models are widely used on environmental analysis and are suitable to simulate the transport of dissolved scalars in the water. They simulate advective and diffusive transports and represent decay or increasing rates of the target property. In the present study, this model was coupled to the hydrodynamic model in order to verify the salinity dispersion in the study area. This coupling is necessary since the salinity is an active tracer and it can interfere on the hydrodynamics [13].

The salinity dispersion model is depth integrated and defined as in:

$$
\begin{aligned}
\frac{\partial \hat{C}}{\partial t}+\hat{u}_{i} \frac{\partial \hat{C}}{\partial x_{i}} & =\frac{1}{H} \frac{\partial}{\partial x_{i}}\left(H \hat{D}_{i j}^{T} \frac{\partial \hat{C}}{\partial x_{j}}\right)+\sum R_{P \& C}+\frac{1}{H}\left(q_{p}\left(C_{p}-\hat{C}\right)-q_{e}\left(C_{e}-\hat{C}\right)\right) \\
& +\frac{1}{H}\left(q_{\text {in }}\left(C_{\text {in }}-\hat{C}\right)-q_{e x}\left(C_{e x}-\hat{C}\right)\right)
\end{aligned}
$$

where $\hat{C}$ is the average salinity along the water column, $\hat{u}_{i}$ is the zonal barotropic velocity component, $H$ is the total depth, $\hat{D}_{i j}^{T}$ is turbulent diffusivity tensor, $R_{P \& C}$ is the kinetic reactions of tracer production and consumption, $q_{p}$ is the precipitation, $q_{e}$ is the evaporation, $q_{\text {in }}$ is infiltration and $q_{e x}$ is the water exfiltration.

The hydrodynamic and dispersion simulations were realized in an unstructured grid with a minimum resolution of $280 \mathrm{~m}$ on the open boundary. The local bathymetry was interpolated in the numerical grid using information from the Brazilian Navy nautical charts. The numerical grid and the local bathymetry are presented in Figure 1.

Twelve hydrodynamic scenarios were used to evaluate the saline intrusion in the studied river. These scenarios comprise different combination of astronomical tide conditions, storm surge amplitudes and the rise of $0.5 \mathrm{~m}$ on the SL, as shown in Table 1. This value was used based on the predictions for global SL and Brazilian coast [6] [7].

Table 1. Scenarios and conditions of tides, storm surges and relative sea level (SL) used on hydrodynamic simulations.

\begin{tabular}{cccc}
\hline Scenario & Astronomical tide & Storm surge $(\mathrm{m})$ & SL $(\mathrm{m})$ \\
\hline 1 & Spring & - & - \\
2 & Neap & - & - \\
3 & Spring & 0.40 & - \\
4 & Neap & 0.40 & - \\
5 & Spring & 0.80 & - \\
6 & Neap & 0.80 & - \\
7 & Spring & - & 0.5 \\
8 & Neap & - & 0.5 \\
9 & Spring & 0.40 & 0.5 \\
10 & Neap & 0.40 & 0.5 \\
11 & Spring & 0.80 & 0.5 \\
12 & Neap & 0.80 & 0.5 \\
\hline
\end{tabular}


Tides were included as boundary conditions based on the predictions for the tidal constituents from Itaguaí Port tidal station. Along the grid boundaries, this forcing presented a spatial variation by the use of a phase lag that was considered in function of the distance and the average depth.

In addition to the tidal forcing and the particular conditions for each scenario, the model was forced by hourly surface winds, measured in a meteorological station from INMET (Instituto Nacional de Meteorologia) located in Angra dos Reis (at $23.00^{\circ} \mathrm{S}$ and $44.32^{\circ} \mathrm{W}$ ). The salinity values used as initial and boundary conditions were measured by the State Environmental Agency (INEA) during its monitoring campaigns along Sepetiba Bay.

The fluvial flow of some rivers including Saco do Engenho $\left(0.5 \mathrm{~m}^{3} / \mathrm{s}\right)$, Mazomba River $\left(1.4 \mathrm{~m}^{3} / \mathrm{s}\right)$, Itaguaí River $\left(0.1 \mathrm{~m}^{3} / \mathrm{s}\right)$, Guarda River $\left(5.5 \mathrm{~m}^{3} / \mathrm{s}\right)$, Santo Agostinho Canal $\left(28.4 \mathrm{~m}^{3} / \mathrm{s}\right)$, Guandú Canal $\left(2.8 \mathrm{~m}^{3} / \mathrm{s}\right)$ and Itá Canal $\left(3.2 \mathrm{~m}^{3} / \mathrm{s}\right)$ were used in the modeling. The average river flows were considered as permanent and used as boundary conditions.

Water volume releases and uptakes by the main water users, mainly corresponding to energy and siderurgy sectors, were also included as sinks and sources of water volume. The sum of all uptakes in the modeled region of São Francisco Canal corresponds to $53.9 \mathrm{~m}^{3} / \mathrm{s}$ and the total release of water is realized to Guandú Canal corresponding to $20.1 \mathrm{~m}^{3} / \mathrm{s}$.

Each experiment was performed using an integration time of 15 days. The experiment results were used to compare the differences between scenarios with SL rise and with the present SL.

\section{Results}

In this section, the hydrodynamic and the salinity dispersion results are presented aiming to verify the main changes observed after the consideration of a SL rise due to a future climate scenario.

\subsection{Hydrodynamic Results}

The Sepetiba bay is a semi-enclosed body and its hydrodynamics basically depends on the action of tides, winds and river flows. Because of this, they are the same factors influencing the water level on São Francisco Canal. The variations on the water level observed in the canal were verified with model results. In Figure 2 , it is possible to verify that the free-surface displacement computed in a grid point located inside the canal, as showed in Figure 1, varies according to the occurrence of storm surges, which are observed up to eight days on average. In Figure 3, the results considering the SL rise are presented and it is possible to observe the same pattern in spite of the high levels due to the SL rise of $0.5 \mathrm{~m}$.

Changes on the velocity fields in response to the increasing sea level due to climate change, tide condition and storm surges were observed along the canal. In Figure 4 it is presented the extreme position where inward currents were observed for each scenario. It is noted that the maximum intrusion occurs on Scenario 11, followed by Scenarios 9 and 5. These three scenarios correspond to 


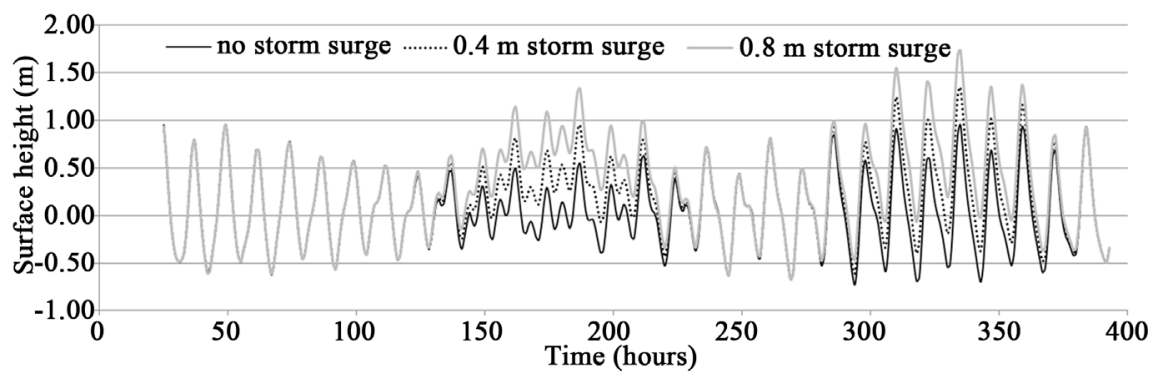

Figure 2. Surface heights computed for the current SL at the station indicated in Figure 1 considering scenarios with no storm surge (scenarios 1 and 2-black line); with $0.4 \mathrm{~m}$ (Scenarios 3 and 4-dotted line); and with $0.8 \mathrm{~m}$ of amplitude due to a storm surge event (Scenarios 5 and 6-gray line).

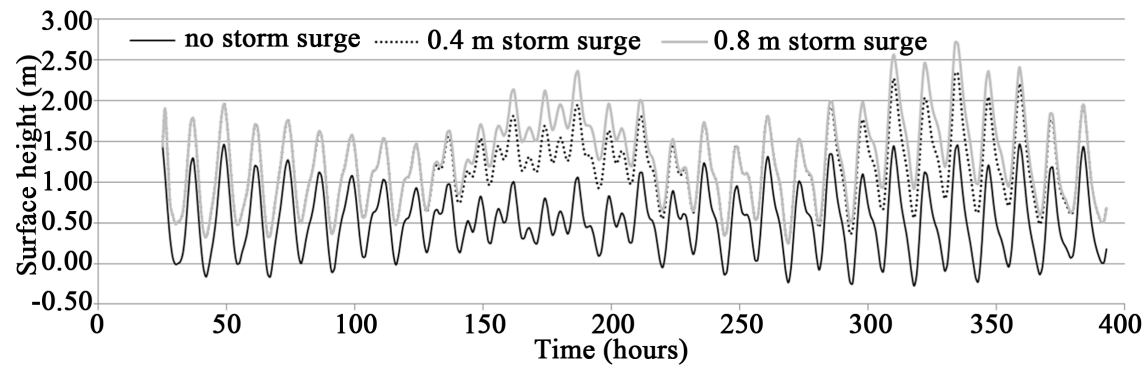

Figure 3. Surface heights computed for the future SL at the station indicated in Figure 1 considering scenarios with no storm surge (Scenarios 7 and 8-black line); with $0.4 \mathrm{~m}$ (Scenarios 9 and 10-dotted line); and with $0.8 \mathrm{~m}$ of amplitude due to a storm surge effect (Scenarios 11 and 12-gray line).

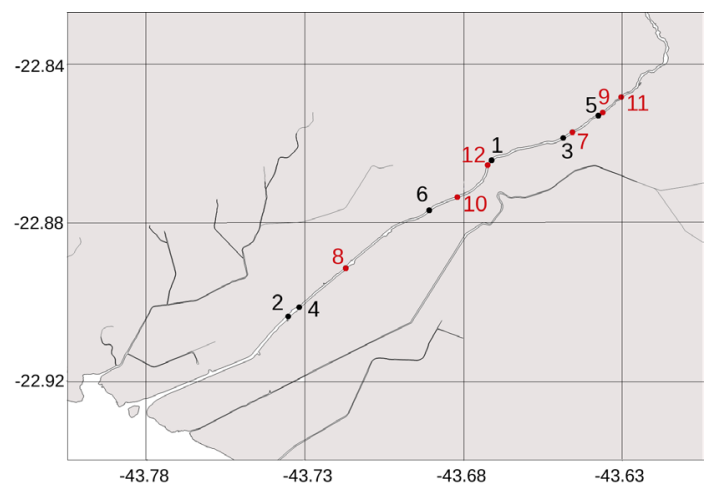

Figure 4. Position of flux inversion limits on spring tide for all scenarios (presented in Table 1) in São Francisco Canal. Red numbers correspond to sea level rise scenarios.

spring tide situations. Scenario 11 corresponds to the combined effect of mean SL rise and the presence of a storm surge event with $0.8 \mathrm{~m}$ of amplitude, and the second greatest intrusion was observed on the scenario that considers the mean SL rise in conjunction with the occurrence of storm surge event with $0.4 \mathrm{~m}$ of amplitude.

However, the third maximum intrusion was observed in the results obtained on Scenario 5, not on Scenario 7, showing, in this case, that the effect of the storm surge $(0.80 \mathrm{~m})$ during spring tide periods suppresses the effect of the mean SL change. Nevertheless, the impact of SL rise (Scenario 7) was greater 
than the impact with the scenario which just considers the effect of a storm surge with $0.4 \mathrm{~m}$ of amplitude (Scenario 3).

With the Scenario 1, that is the mildest of spring tide scenarios, the position of the upstream currents is near to the position verified on Scenario 12 results that represent a condition of neap tide with SL rise and $0.8 \mathrm{~m}$ of storm surge. Among the other neap tide scenarios, it was maintained the same relationships observed between spring tide scenarios.

In general, during neap tides, smaller impacts are observed on water levels and on upstream currents than during spring tide periods. However, considering worsening factors, as the SL rise and the presence of storm surge with higher amplitudes, the sea water from Sepetiba bay advances along the canal.

\subsection{Saline Intrusion}

The differences on the salinity concentrations in São Francisco Canal are presented by the average and maximum values computed in each scenario. Considering the extreme values obtained with the model results, the displacement of the mean SL was not main responsible for the higher values, as can be observed in Figure 5. Comparing scenario 1 and 7, it is possible to verify that during a spring period with no storm surges, higher salinity values are not correlated to the SL rise. The same is observed during neap tide periods (red bars in Figure 5). Nevertheless, considering the combined effect of storm surges and spring tides, extreme values are observed with the SL rise (Figure 5).

Considering the average salinity obtained in each scenario, in general higher salinity values were computed on SL scenarios (Figure 6), both during neap and spring tide periods. The highest averaged salinity was computed in scenario 11, corresponding to a SL rise scenario with the effect of storm surges and spring tides.

On scenarios with the effect of storm surges with $0.8 \mathrm{~m}$ of height and the SL rise (Scenarios 11 and 12), concentrations above the national normative limits (0.5) for this type of water body were observed for longer periods (Figure 7).

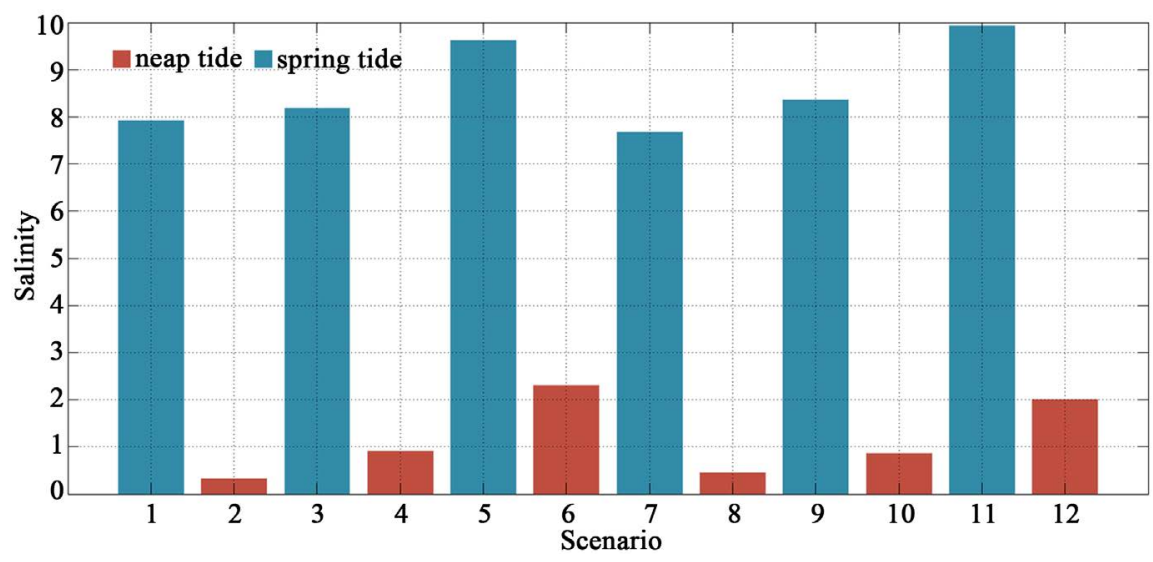

Figure 5. Maximum salinity values computed in each modeling scenario presented in Table 1 at the station located inside the São Francisco canal as shown in Figure 1. The blue and red bars represent spring and neap tide scenarios, respectively. 


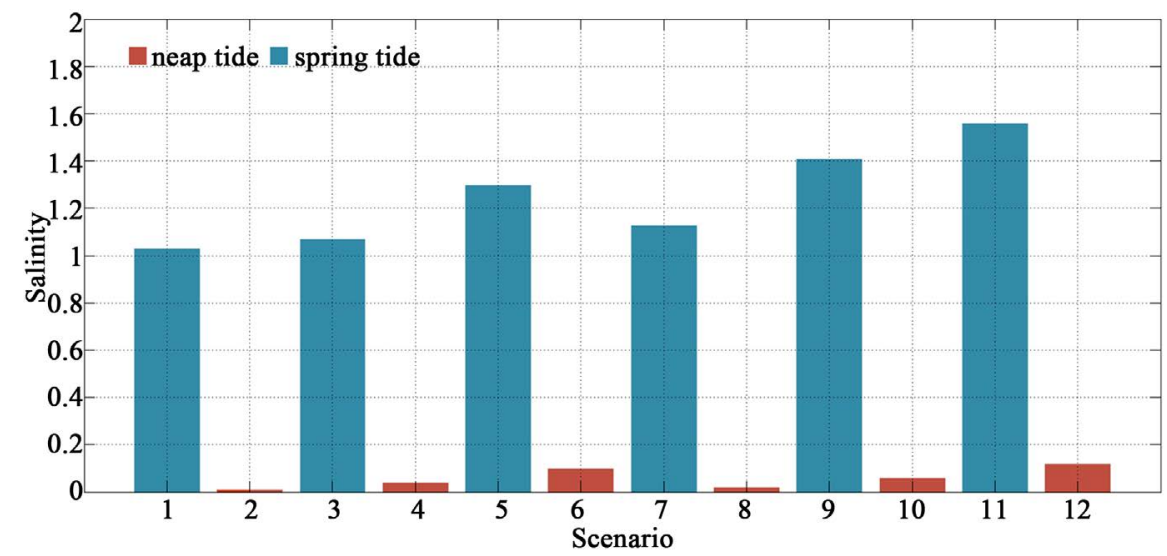

Figure 6. Average salinity values computed in each modeling scenario presented in Table 1 at the station located inside the São Francisco canal as shown in Figure 1. The blue and red bars represent spring and neap tide scenarios, respectively.

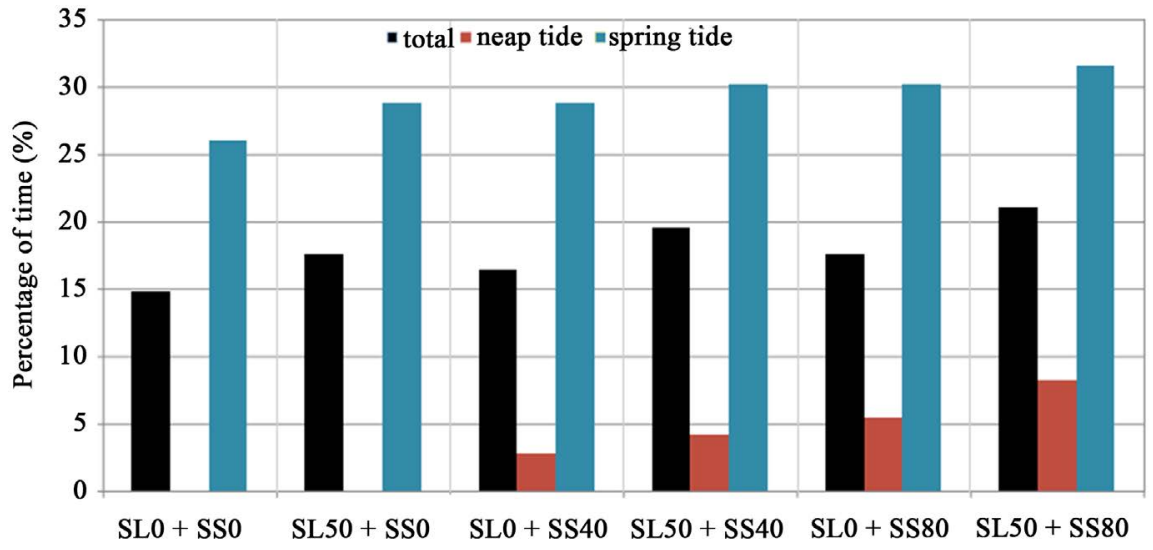

Figure 7. Percentage of simulation time with salinity values greater than 0.5 at the station located inside São Francisco Canal, considering neap and spring periods (black bars), only spring periods (blue bars) and only neap periods (red bars). SL0 indicates no sea level rise and SL50 represents $0.5 \mathrm{~m}$ of rise. SS0 represents conditions with no storm surge occurrence, SS40 represents the occurrence of storm surges with $0.4 \mathrm{~m}$ of height and SS80 with $0.8 \mathrm{~m}$.

The average salinity values for these two scenarios also indicate this pattern (Figure 6).

Both average salinity values and the maximum inward position of the salt wedge indicate that the worse water quality condition is obtained in response to the advance of the surface currents along the river. Therefore, higher saline intrusions are observed with the SL rise and during the spring tide, being more intense in accordance to the amplitude of storm surges.

\section{Discussion}

There are three strategies to reduce coastal vulnerability. These strategies are: protection, when the risk is minimized due to the reduction on its occurrence probability; retreat, when the risk is reduced by the limitation on its potential effects; and accommodation, when the capacity of the society to recover itself from 
the effects is increased [14].

In the case of SL rise, protection would mean the reduction on GHG emissions, but, even if the emissions are stabilized in the next decades, a significant increase on SL should occur due to the temperature differences between oceanic layers [15]. Furthermore, currently there is no conclusive knowledge that relates climate changes to GHG emissions. Then, this strategy would not be suitable for this problem. Other interpretation would be through engineering interventions in order to preserve the present human occupation on coastal zones, as by the construction of barriers and dykes, but it is usually an expensive measure.

Retreat means the abandonment of present occupations and improvements, and the migration toward the continent. It is suitable for new occupations, when the new land uses would be projected according to the SL rising. However, considering intensely occupied waterfront areas, the alternative would be the combination of retreat and accommodation strategies, adapting the coastal zone to the new SL [5].

According to Titus (1991), in established coastal areas, engineering interventions should be used, and, when these protection measurements are expensive, they should be replaced by accommodation ones. Retreat strategies, according to Titus, are only appropriate in underdeveloped areas, with few investments in infrastructure, or where is possible to occur a natural adaptation [16]. Despite the interest on accommodation and retreat strategies in the environmental management of coastal zones, an integrated approach with coastal management is still necessary [14].

In Brazil, the National Policy on Climate Change (PNMC, from Portuguese), recognized by the Federal Law n. 12,187/2009, establishes principles to avoid, predict and minimize climate change due to anthropogenic causes, aiming to adopt adaptation measures and integrated mitigation and adaptation strategies in local, regional and national spheres.

In Rio de Janeiro, the Law n. 5690/2010 establishes principles, aims, guidelines and instruments to adapt and prevent climate change negative effects, similar, in general, to those on National Policy. Among these instruments, economic-ecological zoning is important in light of the SL rise. However, environmental licensing, as contained in the Law, is just related to the control of GHG emissions by license applicants and it does not state about the local vulnerabilities to climate changes in installation site and the possible effect of this licenses on this vulnerability. Both in National and State policies, these issues are not addressed.

The state of Rio de Janeiro has been frequently affected by extreme rainfall events. Even though the frequency of these events is not related to the global climate change, they show the possible consequences of these changes [17]. The coastal area of Rio de Janeiro has been reported as vulnerable to SL rise and to the occurrence of extreme events, including storm surge events, worsening runoff problems and coastal flooding [17]. The continental margin of the Sepetiba Bay is considered one of the most vulnerable areas to SL rise in Rio de Janeiro [17] and the results of the present work exemplify that. 
Observing the changes in response to the future SL rise, the flood currents reached more than $19 \mathrm{~km}$ along the São Francisco Canal considering the most extreme scenario. Higher water levels were also observed along the canal, of about $2.72 \mathrm{~m}$, while under normal conditions this value only reaches $0.96 \mathrm{~m}$ during spring tides.

Comparing the results from hydrodynamic and transport models, the highest salinity concentrations are not observed in scenarios with higher water elevations, but in scenarios where the stream inversion limits occurred upstream on the canal.

The most extreme scenario (storm surge, spring tide and SL rise) presented an average increase of $52 \%$ on salinity values in relation to the milder scenario and of $22 \%$ in relation to the corresponding scenario (storm surge and spring tide) with no SL rise. Thus, it is possible to verify that an increase of $0.5 \mathrm{~m}$ in the local SL would increase the salinity in the San Francisco Canal, what would deteriorate water quality. This increase is mainly evidenced by the further advancement of the salt wedge, affecting upstream areas.

According to the results, the SL rise would lead the salt wedge $450 \mathrm{~m}$ upstream along the river, comparing the results between Scenarios 1 and 7. Considering the effect of storm surges with amplitudes of 0.40 and $0.80 \mathrm{~m}$, during the periods of spring tide, the differences in response to the SL rise are of 380 and $267 \mathrm{~m}$, respectively.

The saline intrusion obtained in scenario 11 that corresponds to the most extreme situation, is positioned $4.4 \mathrm{~km}$ and $0.8 \mathrm{~km}$ upstream to the positions obtained with the milder scenarios, representing the period of neap and spring tides, respectively. The maximum intrusion was observed at $5.4 \mathrm{~km}$ from the river mouth.

This same type of analysis was performed by [18] in the Gorai River basin in Bangladesh. Considering a SL rise of $0.59 \mathrm{~m}$, the authors verified an increase of 0.9 in salinity values, $80 \mathrm{~km}$ upstream of the mouth, representing a salinity increase of 1.5 per meter of elevation. Their results demonstrated for the region that this intrusion would result in socioeconomic problems, especially in agriculture and aquaculture activities.

Despite the saline wedge intrusion in São Francisco Canal is not as extensive as that of the Gorai River, salinity concentrations ranged approximately in accord to the proportion cited by the authors. Near to the mouth of São Francisco Canal, the salinity increased on the average in a rate of 1.4 per meter of SL rise.

It is necessary to note that other changes besides SL rise were not considered in the present case study. However, it is easy to assume that in a future scenario, environmental conditions will be different from the current scenario, especially considering the effects from climate changes. Thus, future bathymetric and morphological conditions, as well as winds and rainfall rates, and therefore, river flows, could cause significant changes in the results presented in this work. These considerations may lead to the worsening or the attenuation of the results.

Thus, comprehensive studies on the local conditions are necessary to allow the 
strategic planning of water resources in the studied river basin, considering the imminent interference of climate change on water availability. Moreover, previous studies on the effects of climate change show that the water management in coastal areas should be made considering the potential saline wedge intrusions.

However, such planning is a complicated achievement as it is needed to consider the best water extraction locations and to control the water quality [19]. An efficient system can be obtained by considering all flow extractions, in order to previously predict the amount of river flow or reservoir volume that will decrease. However, this type of analysis is complex, given the degree of uncertainty associated with climate predictions, and due to disagreements regarding the responsibilities and investment needs, as climate change time cycle and the political cycle occur in very different time scales [7]. Thus, the choice of proactive attitudes is often left out, delaying the planning and the consideration of these atmospheric and environmental variables on the land use management, even if they are part of government policies.

The sustainable exploitation of aquifers, according to some researchers, may be the solution to prevent the degradation by saltwater intrusion. However, it does not seem feasible for aquifers in broad expansion. São Francisco Canal, because of its location, becomes strategic for industrial use, especially because it is located nearby Itaguaí Port, which attracts the establishment of a range of economic sectors in the region.

According to the strategic plan for the region of Guandu river basin, some criteria must be considered in the implementation of new raw water users [20]. Currently, the fluvial flow downstream of Pereira Passos HPP is $120 \mathrm{~m}^{3} / \mathrm{s}$, but after current water uptakes only 7.3\% returns to the system and reach the Sepetiba Bay.

In this context, new water transfers must be carefully evaluated. As Guandu river flow depends on the present transfer from Paraíba do Sul River, even possible new transfers of water from this source could pose risks in maintaining the required flow to control the saltwater intrusion along the São Francisco Canal. Additionally, new water uptakes in Paraíba do Sul River could possibly exacerbate adverse conditions considering future climate change scenarios, such as drought extremes in river headwaters.

Thus, water resource and coastal managements must be integrated and in accordance with the principles stated in climate change policies to ensure that the environmental quality will be maintained. In addition, to turn possible the maintenance of the current water withdrawals and the establishment of new grants, it is necessary a thorough study of climate variables and considering them in the licensing process, in order to do not compromise the water supply and to choose strategies to reduce the vulnerability of the coastal zone.

\section{Conclusions}

In the present work, the effect of the sea level rise on water resources was eva- 
luated in a river located in the region of Sepetiba Bay, Rio de Janeiro, Brazil. Using numerical modeling, changes on water levels and on canal hydrodynamics were observed. The upstream currents during rising tides would be more intrusive due to the intensification of pressure gradients in response to future SL rise.

This is an important result as climate change on the numerical modeling was just included as the SL displacement. Then, the modeled changes correspond just to the response to the modification on the SL and do not comprise the combined effects in consequence of this rise, as the increasing on wave heights near to the shore, due to the decreased bottom friction, and the morphological changes, due to the intensification on transport processes.

Resulting from these modeled hydrodynamical changes, the water quality along the river would be injured, in which more areas influenced by saline waters would be observed so as the increasing on salinity values at the river points previously affected by saline intrusion. The rise of $0.5 \mathrm{~m}$ on the mean SL would lead to a salt wedge intrusion up to $5.4 \mathrm{~km}$ away from the river mouth, affecting water uptakes of some industries established in the region.

The present results illustrate how this coastal environment would respond to sea level changes, however, further investigations are needed to better understand the water availability in a future climate scenario. Nevertheless, the potential future degradation on São Francisco Canal water quality indicates that future water grants should be evaluated by the local environmental agencies after considering climate scenarios. The decreasing on fluvial flow in the studied river would lead to more intense saline intrusion.

Finally, it is recommended the consideration of climate change effects along the environmental licensing, in order to establish suited strategies for each type of project and for each implementation area, and the integration between water resources and coastal management. Thus, it would be possible to determine the most vulnerable areas where major investments are needed and to manage the coastal environment according to charts of climate change vulnerability.

\section{Acknowledgements}

The authors would like to thank the CNPq (National Council of Technological and Scientific Development) for the financial support.

\section{References}

[1] IPCC (2007) Climate Change 2007: The Physical Science Basis. Contribution of Working Group I to the Fourth Assessment Report of the Intergovernmental Panel on Climate Change. Cambridge University Press, Cambridge.

[2] Church, J.A. and White, N.J. (2006) A 20th Century Acceleration in Global Sea-Level Rise. Geophysical Research Letters, 33, 4 p. https://doi.org/10.1029/2005GL024826

[3] Santos, R.F. and Caldeyro, V.S. (2007) Paisagens, Condicionantes e Mudanças. In: Vulnerabilidade Ambiental-Desastres Naturais ou Fenômenos Induzidos? Santos, R. F. Org., Brasília, 192 p.

[4] Tagliani, C.R., Calliari, L.J., Tagliani, P.R. and Antiqueira, J.A. (2010) Vulnerability to Sea Level Rise of an Estuarine Island in Southern Brazil. Quaternary and Envi- 
ronmental Geosciences, 1, 18-24. https://doi.org/10.5380/abequa.v2i1-2.12821

[5] Neves, C.F. and Muehe, D. (2008) Vulnerabilidade, Impactos e Adaptação às Mudanças do Clima: A Zona Costeira. In: Parcerias Estratégicas: Mudança do Clima No Brasil: Vulnerabilidade, Impactos e Adaptação, Brasília.

[6] Church, J.A., Clark, P.U., Cazenave, A., et al. (2013) Sea Level Change. In: Stocker, T.F., Qin, D., Plattner, G.K., et al., Eds., Climate Change 2013: The Physical Science Basis, Cambridge University Press, Cambridge.

[7] Belém, A.L. (2007). Impactos das Mudanças Climáticas Globais No Risco de Inundações em Zonas Costeiras. Jornadas Internacionales sobre Gestión del Riesgo de Inundaciones y Deslizamientos de Laderas. Brazil, $13 \mathrm{p}$.

[8] Chang, S.W., Clement, T.P., Simpson, M.J. and Lee, K. (2011) Does Sea-Level Rise Have an Impact on Saltwater Intrusion? Advances in Water Resources, 34, 1283 1291. https://doi.org/10.1016/j.advwatres.2011.06.006

[9] Abd-Elhamid, H.F. and Javadi, A.A. (2011) Impact of Sea Level and Over-Pumping on Seawater Intrusion in Coastal Aquifers. Journal of Water and Climate Change, 2, 19-28. https://doi.org/10.2166/wcc.2011.053

[10] Niang, I., Dansokho, M., Faye, S., Gueye, K. and Ndiaye, P. (2010) Impacts of Climate Change on the Senegalese Coastal Zones: Examples of the Cap Vert Peninsula and Saloum Estuary. Global and Planetary Change, 72, 294-301. https://doi.org/10.1016/j.gloplacha.2010.01.005

[11] Molisani, M.M., Kjerfve, B., Silva, A.P. and Lacerda, L.D. (2006) Water Discharge and Sediment Load to Sepetiba Bay from an Anthropogenically-Altered Drainage Basin, SE Brazil. Journal of Hidrology, 331, 425-433.

[12] Rosman, P.C.C. (2013) Referência Técnica do SisBaHia. 249 p. http://www.sisbahia.coppe.ufrj.br/SisBAHIA_RefTec_V92.pdf

[13] Rosman, P.C.C. (1997) Subsídios Para Modelagem de Sistemas Estuarinos. In: Rosman, P.C.C., Almeida, A.B., Eiger, S., Eds., Métodos Numéricos em Recursos Hídricos, 3rd Edition, ABRH, Porto Alegre, 238-348.

[14] Klein, R.J.T., Nicholls, R.J., Ragoonaden, S., Capobianco, M., Aston, J. and Buckley, E.N. (2001) Technological Options for Adaptation to Climate Change in Coastal Zones. Journal of Coastal Research, 17, 591-543.

[15] Wigley, T.M.L. (1995) Global-Mean Temperature and Sea Level Consequences of Greenhouse Gas Concentration Stabilization. Geophysical Research Letters, 22, 4548. https://doi.org/10.1029/94GL01011

[16] Titus, J.G. (1991) Greenhouse Effect and Sea Level Rise: The cost of Holding Back the Sea. Coastal Management, 19, 171-204. https://doi.org/10.1080/08920759109362138

[17] Gusmão, P.P. (2010) Vulnerabilidade das Megacidades Brasileiras às Mudanças Climáticas: Região Metropolitana do Rio de Janeiro. In: Nobre, C. and Hogan, D.J., Eds., Projeto Megacidades, Vulnerabilidade e Mudanças Climáticas. INPE/UNICAMP/UFRJ, $32 \mathrm{p}$.

[18] Bhuiyan, M.J.A.N. and Dutta, D. (2012) Assessing Impacts of Sea Level Rise on River Salinity in the Gorai River Network, Bangladesh. Estuarine, Coastal and Shelf Science, 96, 219-227. https://doi.org/10.1016/j.ecss.2011.11.005

[19] Ferreira Da Silva, J. and Haie, N. (2007) Optimal Locations of Groundwater Extractions in Coastal Aquifers. Water Resources Management, 21, 1299-1311. https://doi.org/10.1007/s11269-006-9082-7

[20] ANA (2007) Water National Agency (Agência Nacional de Águas). Plano Estratégico de Recursos Hídricos das Bacias Hidrográficas dos Rios Guandu, da Guarda e Guandu Mirim: Relatório Gerencial. Brasília, 63 p. 
Submit or recommend next manuscript to SCIRP and we will provide best service for you:

Accepting pre-submission inquiries through Email, Facebook, LinkedIn, Twitter, etc. A wide selection of journals (inclusive of 9 subjects, more than 200 journals)

Providing 24-hour high-quality service

User-friendly online submission system

Fair and swift peer-review system

Efficient typesetting and proofreading procedure

Display of the result of downloads and visits, as well as the number of cited articles Maximum dissemination of your research work

Submit your manuscript at: http://papersubmission.scirp.org/

Or contact jwarp@scirp.org 